\title{
Identifikasi Tanaman Obat-Obatan Sebagai Elemen Lunak Lansekap di Kecamatan Kediri, Kabupaten Tabanan, Provinsi Bali
}

\author{
LUH RATIH PARAMITA ${ }^{1}$, SANG MADE SARWADANA ${ }^{2 *}$, \\ I NYOMAN GEDE ASTAWA ${ }^{1}$
}

1. Program Studi Agroekoteknologi, Fakultas Pertanian, Universitas Udayana, JI. PB. Sudirman, Denpasar 80232 Bali, Indonesia

2. Program Studi Arsitektur Pertamanan, Fakultas Pertanian, Universitas Udayana, JI. PB. Sudirman, Denpasar 80232 Bali, Indonesia

*E-mail: sarwadana55@gmail.com

\section{ABSTRACT \\ Indentification of the Medicinal Plants as a Landscape Softscape Element in District of Kediri, Tabanan Regency, Province of Bali}

Indonesia is an agricultural country known for the wealth of species and different kinds of plants. Diversity of natural resources make Indonesia has a lot of biodiversity as well as the diversity of traditional medical plants, or more commonly known herbs.Medical plants flowering in the regional in Kediri, Tabanan regency, Province of Bali still very little is used as an softscape element of landscape, so it has not been used optimally. Presumably there are many kinds of medical plant other throughout in Kediri, Tabanan regency, Province of Bali either cultivated or growing wild. Have data regarding a kinds of medical plants in the region is very important both for science and conservation. Medical plants have potential as an ornamental plant, because the flowers can give a feeling of luxury, so there will be a sense of pride by the owner. Medical plants can be used as landscape softcape elements, besides being able to used aesthetics value of the plants and when necessary for health will be easier to get it. This method of technique sampling used survey, questionnaires, and interview. The results of this those there are 52 species of medical plants which are grouped into five flowering habitus are bushes, shrubs, water plants, trees, and ground cover.There are four function of medical plants has inventory and identification as an element of landscape design is as a railings, shade, absorbing pollutants and aesthetics value.

Keywords: inventory, identification, medical plants flowering, softscape element.

\section{Pendahuluan}

\subsection{Latar belakang}

Indonesia merupakan negara agraris yang terkenal akan kekayaan rempah rempah dan berbagai jenis tanaman. Indonesia dikenal sebagai gudangnya tanaman obat, sehingga mendapat julukan live laboratory (Wijayakusuma, 2007). Keanekaragaman 
sumber daya alam membuat Indonesia memiliki banyak keanekaragaman hayati termasuk juga keanekaragaman tanaman obat tradisional atau lebih sering dikenal dengan tanaman herbal. Tanaman obat-obatan berbunga di Daerah Kecamatan Kediri, Kabupaten Tabanan, Provinsi Bali masih sangat sedikit digunakan sebagai elemen desain lansekap, sehingga belum dimanfaatkan secara optimal. Masih banyak jenis tanaman obat-obatan yang berbunga lainnya di seluruh Kecamatan Kediri, Kabupaten Tabanan, Provinsi Bali, yang dibudidayakan maupun tumbuh secara liar. Wilayah yang memiliki data lengkap mengenai suatu jenis tanaman obat-obatan sangat penting artinya baik untuk ilmu pengetahuan dan melestarikannya. Tanaman obat-obatan dapat digunakan sebagai elemen lunak lansekap, karena memiliki fungsi yang ganda karena selain dapat dinikmati keindahan tanamannya dan ketika diperlukan untuk kesehatan akan lebih mudah untuk mendapatkannya.

Rumusan masalah dari penelitian ini adalah mengenai jenis tanaman obat-obatan apa saja yang dapat dijadikan sebagai elemen lunak lansekap di Kecamatan Kediri, Kabupaten Tabanan, Provinsi Bali serta belum dikelompokkannya jenis-jenis tanaman tersebut ke dalam jenis elemen lunak lansekap. Selain itu juga mengenai fungsi tanaman obat-obatan berbunga sebagai tanaman lansekap yang belum banyak diketahui. Oleh karena itu tujuan dilakukannya penelitian ini adalah yang pertama untuk menginventarisasi dan mengidentifikasi jenis tanaman obat-obatan berbunga yang ada di Kecamatan Kediri, Kabupaten Tabanan, Provinsi Bali. Berikutnya untuk mengelompokkan tanaman obatobatan dalam elemen lunak lansekap dan terakhir adalah dalam rangka mengetahui fungsi tanaman obat-obatan sebagai elemen lansekap.

Adapun untuk memperluas pengetahuan masyarakat tentang potensi tanaman obat-obatan yang dapat digunakan sebagai elemen lunak lansekap.

1. Mengantisipasi kejenuhan akan jenis tanaman yang sudah beredar di masyarakat dan menambah keragaman tanaman hias.

2. Hasil dari penelitian ini dapat digunakan sebagai data dasar untuk penelitian lebih lanjut mengenai potensi tanaman obat-obatan yang dapat digunakan sebagai elemen desain lansekap.

\section{Metode}

\subsection{Waktu dan Tempat}

Penelitian dilaksanakan di tempat yang terdapat atau memiliki tanaman obatobatan di Kecamatan Kediri, Kabupaten Tabanan, Provinsi Bali. Penelitian dilaksanakan selama 4 bulan yang dimulai dari Maret sampai Juni tahun 2016.

\subsection{Alat}

Alat yang dibutuhkan dalam penelitian ini ialah berupa lembaran kuesioner, alat ukur (meteran), kamera digital, serta komputer untuk mengolah data dengan menggunakan software Microsoft Office Word dan Microsoft Excel 2007.

\subsection{Metode Penelitian}

Metode penelitian yang digunakan dalam penelitian ini adalah metode survei.

\subsection{Teknik Pengumpulan Data}


a). Survei

Merupakan metode pengumpulan data dengan mendatangi langsung lokasi yang dijadikan objek penelitian. Survei akan dilakukan pada tempat tumbuhnya tanaman obatobatan berbunga di Kecamatan Kediri, Kabupaten Tabanan, Provinsi Bali.

b). Wawancara

Pengambilan data dengan cara menanyakan kepada responden, caranya adalah dengan bertanya langsung atau tanya jawab dengan tatap muka kepada responden dengan menggunakan daftar pertanyaan yang sudah disiapkan. Wawancara dilakukan terhadap masyarakat di Kecamatan Kediri, Kabupaten Tabanan, Provinsi Bali.

c). Kuisioner

Suatu metode dengan cara memberikan pertanyaan yang berstruktur dan sitematis yang diisi sendiri oleh sejumlah responden yang sudah ditentukan. Jenis kuisioner yang digunakan ialah kuisioner tertutup yang dapat mengarahkan responden untuk menjawab pertanyaan dan membatasi responden dalam mengisi kuisioner.

d). Studi Kepustakaan

Jenis data ini dapat berupa data sekunder yang dapat diperoleh dari jurnal hasil penelitian, buku-buku ilmiah, laporan penelitian, tulisan ilmiah, tesis dan disertasi, ensiklopedia dan sumber-sumber tertulis tercetak maupun elektronik lain.

\subsection{Metode Analisis}

Metode analisis yang dipakai ialah walkthrough survey (Harrington dan Gill, 2008), survei yang dilakukan dengan cara membawa borang (daftar nama) yang telah diisi dengan nama tanaman obat yang telah diketahui di daerah Bali, sehingga keberadaan tanaman obat di tempat survei hanya dengan memberi tanda rumput pada kolom nama tanaman obat yang ada pada wilayah tersebut. Cara pengambilan sampel dalam sampel responden yang diambil dalam penelitian ini menggunakan teknik purposive sampling. Jumlah sampel dalam penelitian ini ditetapkan 34 rumah yang dapat mewakili kriteria sebagai berikut : rumah penduduk asli di wilayah desa Kecamatan Kediri dan memiliki tanaman obat-obatan berbunga. Area rumah yang dijadikan sebagai lokasi pengambilan data tanaman obat-obatan berbunga yaitu di pekarangan rumah, telajakan, dan di tegalan.

\section{Hasil dan Pembahasan}

\subsection{Hasil Identifikasi}

Penelitian ini menemukan adanya 52 jenis tanaman obat-obatan berbunga ditemukan di telajakan, pekarangan rumah dan tegalan. Tanaman obat-obatan berbunga yang didapat di Kecamatan Kediri antara lain:

Tabel 1. Hasil Identifikasi Tanaman Obat-obatan di Kecamatan Kediri, Kabupaten Tabanan

\begin{tabular}{|c|c|c|c|c|c|c|}
\hline No & Nama Tanaman & Fungsi dalam lansekap & Habitus & $\begin{array}{c}\text { Tempat } \\
\text { Ditemukan }\end{array}$ & Manfaat Obat & Jumlah \\
\hline 1 & $\begin{array}{l}\text { Alamanda } \\
\text { (Allamanda } \\
\text { cathartica) }\end{array}$ & $\begin{array}{l}\text { Sebagai tanaman hias atau nilai } \\
\text { estetika }\end{array}$ & Perdu & $\begin{array}{l}\text { Telajakan dan } \\
\text { Pekarangan } \\
\text { rumah }\end{array}$ & $\begin{array}{l}\text { meredakan demam dan } \\
\text { mengobati penyakit kurap }\end{array}$ & 39 \\
\hline 2 & Bakung air mancur & Sebagai tanaman hias atau nilai & Semak & Telajakan dan & wasir dan menghilangkan & 30 \\
\hline
\end{tabular}




\begin{tabular}{|c|c|c|c|c|c|c|}
\hline No & Nama Tanaman & Fungsi dalam lansekap & Habitus & $\begin{array}{c}\text { Tempat } \\
\text { Ditemukan }\end{array}$ & Manfaat Obat & Jumlah \\
\hline & $\begin{array}{l}\text { (Hymenocallis } \\
\text { littoralis) }\end{array}$ & estetika & & $\begin{array}{l}\text { Pekarangan } \\
\text { rumah }\end{array}$ & bengkak (memar) & \\
\hline 3 & $\begin{array}{l}\text { Biduri (Calotropis } \\
\text { gigantean) }\end{array}$ & $\begin{array}{l}\text { Sebagai tanaman hias atau nilai } \\
\text { estetika }\end{array}$ & Semak & $\begin{array}{l}\text { Pekarangan } \\
\text { rumah dan } \\
\text { tegalan }\end{array}$ & $\begin{array}{l}\text { sariawan, luka, demam } \\
\text { dan batuk }\end{array}$ & 14 \\
\hline 4 & $\begin{array}{l}\text { Binahong } \\
\text { (Anredera } \\
\text { cordifolia) }\end{array}$ & $\begin{array}{l}\text { Sebagai tanaman hias atau nilai } \\
\text { estetika }\end{array}$ & Semak & $\begin{array}{l}\text { Pekarangan } \\
\text { rumah }\end{array}$ & $\begin{array}{l}\text { untuk mengatasi maag } \\
\text { dan mengurangi asam } \\
\text { urat }\end{array}$ & 2 \\
\hline 5 & $\begin{array}{l}\text { Bunga pagoda } \\
\text { (Clerodendrum } \\
\text { japonicum) }\end{array}$ & $\begin{array}{l}\text { Sebagai tanaman hias atau nilai } \\
\text { estetika }\end{array}$ & Perdu & $\begin{array}{l}\text { Telajakan dan } \\
\text { Pekarangan } \\
\text { rumah }\end{array}$ & $\begin{array}{l}\text { wasir dan menghilangkan } \\
\text { bengkak (memar) }\end{array}$ & 10 \\
\hline 6 & $\begin{array}{l}\text { Bunga lilin } \\
\text { (Pachystachys } \\
\text { lutea) }\end{array}$ & $\begin{array}{l}\text { Sebagai tanaman hias atau nilai } \\
\text { estetika }\end{array}$ & Perdu & $\begin{array}{l}\text { Pekarangan } \\
\text { rumah }\end{array}$ & diare dan cacingan & 3 \\
\hline 7 & $\begin{array}{l}\text { Bungur } \\
\text { (Lagerstroemia } \\
\text { speciosa) }\end{array}$ & Penyerap polutan & Pohon & Telajakan & $\begin{array}{l}\text { tekanan darah tinggi dan } \\
\text { kencing batu }\end{array}$ & 15 \\
\hline 8 & $\begin{array}{l}\text { Beluntas (Pluchea } \\
\text { indica) }\end{array}$ & $\begin{array}{l}\text { Pembatas untuk privasi atau } \\
\text { pagar }\end{array}$ & Perdu & $\begin{array}{l}\text { Pekarangan } \\
\text { rumah }\end{array}$ & $\begin{array}{l}\text { menurunkan panas, } \\
\text { keputihan, dan } \\
\text { melancarkan haid }\end{array}$ & 25 \\
\hline 9 & $\begin{array}{l}\text { Boroco (Celosia } \\
\text { argentea L.) }\end{array}$ & $\begin{array}{l}\text { Sebagai tanaman hias atau nilai } \\
\text { estetika }\end{array}$ & Semak & Tegalan & $\begin{array}{l}\text { infeksi saluran kencing } \\
\text { dan tekanan darah tinggi }\end{array}$ & 2 \\
\hline 10 & $\begin{array}{l}\text { Cempaka (Michelia } \\
\text { champaca) }\end{array}$ & $\begin{array}{l}\text { Tabir untuk mengurangi cahaya } \\
\text { matahari dan sinar lampu } \\
\text { kendaraan }\end{array}$ & Pohon & Telajakan & $\begin{array}{l}\text { demam dan gangguan } \\
\text { pencernaan }\end{array}$ & 50 \\
\hline 11 & $\begin{array}{l}\text { Daun Wungu } \\
\text { (Graptophyllum } \\
\text { pictum) }\end{array}$ & $\begin{array}{l}\text { Pembatas untuk privasi atau } \\
\text { pagar }\end{array}$ & Perdu & $\begin{array}{l}\text { Telajakan dan } \\
\text { Pekarangan } \\
\text { rumah }\end{array}$ & $\begin{array}{l}\text { wasir dan susah buang } \\
\text { air besar }\end{array}$ & 68 \\
\hline 12 & $\begin{array}{l}\text { Jarak (Jatropha } \\
\text { podagrica) }\end{array}$ & $\begin{array}{l}\text { Pembatas untuk privasi atau } \\
\text { pagar }\end{array}$ & Perdu & $\begin{array}{l}\text { Telajakan dan } \\
\text { Pekarangan } \\
\text { rumah }\end{array}$ & $\begin{array}{l}\text { Demam dan memar } \\
\text { (bengkak) }\end{array}$ & 25 \\
\hline 13 & $\begin{array}{l}\text { Jengger ayam } \\
\text { (Celosia cristata L.) }\end{array}$ & $\begin{array}{l}\text { Sebagai tanaman hias atau nilai } \\
\text { estetika }\end{array}$ & Semak & $\begin{array}{l}\text { Pekarangan } \\
\text { rumah }\end{array}$ & $\begin{array}{l}\text { keputihan dan infeksi } \\
\text { saluran kencing }\end{array}$ & 5 \\
\hline 14 & $\begin{array}{l}\text { Kaca piring } \\
\text { (Gardenia augusta) }\end{array}$ & $\begin{array}{l}\text { Pembatas untuk privasi atau } \\
\text { pagar }\end{array}$ & Perdu & $\begin{array}{l}\text { Telajakan dan } \\
\text { Pekarangan } \\
\text { rumah }\end{array}$ & $\begin{array}{l}\text { demam, sesak nafas, dan } \\
\text { sariawan }\end{array}$ & 70 \\
\hline 15 & $\begin{array}{l}\text { Kaktus pakis } \\
\text { giwang (Euphorbia } \\
\text { milii) }\end{array}$ & $\begin{array}{l}\text { Pembatas untuk privasi atau } \\
\text { pagar }\end{array}$ & Semak & $\begin{array}{l}\text { Telajakan dan } \\
\text { Pekarangan } \\
\text { rumah }\end{array}$ & $\begin{array}{l}\text { bisul dan luka tersiram air } \\
\text { panas }\end{array}$ & 69 \\
\hline 16 & $\begin{array}{l}\text { Kamboja (Plumeria } \\
\mathrm{sp)}\end{array}$ & $\begin{array}{l}\text { Sebagai tanaman hias atau nilai } \\
\text { estetika }\end{array}$ & Pohon & $\begin{array}{l}\text { Telajakan dan } \\
\text { Pekarangan } \\
\text { rumah }\end{array}$ & bisul, sakit gigi, dan luka & 192 \\
\hline 17 & $\begin{array}{l}\text { Kamboja pagoda } \\
\text { (Plumeria pudica) }\end{array}$ & $\begin{array}{l}\text { Sebagai tanaman hias atau nilai } \\
\text { estetika }\end{array}$ & Perdu & $\begin{array}{l}\text { Pekarangan } \\
\text { rumah }\end{array}$ & bisul, sakit gigi, dan luka & 9 \\
\hline 18 & $\begin{array}{l}\text { Kapas (Gossypium } \\
\text { herbaceum L.) }\end{array}$ & $\begin{array}{l}\text { Pembatas untuk privasi atau } \\
\text { pagar }\end{array}$ & Perdu & $\begin{array}{l}\text { Pekarangan } \\
\text { rumah }\end{array}$ & $\begin{array}{l}\text { batuk berdahak dan } \\
\text { demam }\end{array}$ & 5 \\
\hline 19 & $\begin{array}{l}\text { Kumis kucing } \\
\text { (Orthosipon } \\
\text { spicatus) }\end{array}$ & $\begin{array}{l}\text { Sebagai tanaman hias atau nilai } \\
\text { estetika }\end{array}$ & Semak & $\begin{array}{l}\text { Pekarangan } \\
\text { rumah }\end{array}$ & $\begin{array}{l}\text { kencing batu, rematik, } \\
\text { dan tekanan darah tinggi }\end{array}$ & 7 \\
\hline 20 & $\begin{array}{l}\text { Kunyit (Curcuma } \\
\text { domestica) }\end{array}$ & $\begin{array}{l}\text { Sebagai tanaman hias atau nilai } \\
\text { estetika }\end{array}$ & Semak & $\begin{array}{l}\text { Pekarangan } \\
\text { rumah dan } \\
\text { tegalan }\end{array}$ & $\begin{array}{l}\text { perut mual, sakit kepala, } \\
\text { maag, dan gigi berlubang. }\end{array}$ & 23 \\
\hline 21 & $\begin{array}{l}\text { Ketepeng cina } \\
\text { (Cassia alata L.) }\end{array}$ & $\begin{array}{l}\text { Sebagai tanaman hias atau nilai } \\
\text { estetika }\end{array}$ & Perdu & Tegalan & $\begin{array}{l}\text { sakit kulit atau panu dan } \\
\text { malaria }\end{array}$ & 2 \\
\hline
\end{tabular}




\begin{tabular}{|c|c|c|c|c|c|c|}
\hline No & Nama Tanaman & Fungsi dalam lansekap & Habitus & $\begin{array}{c}\text { Tempat } \\
\text { Ditemukan }\end{array}$ & Manfaat Obat & Jumlah \\
\hline & $\begin{array}{l}\text { (Zhepyrantthes } \\
\text { candida) }\end{array}$ & estetika & & rumah & menurunkan demam & \\
\hline 23 & $\begin{array}{l}\text { Kecombrang } \\
\text { (Etlingera elatior) }\end{array}$ & $\begin{array}{l}\text { Sebagai tanaman hias atau nilai } \\
\text { estetika }\end{array}$ & Semak & $\begin{array}{l}\text { Pekarangan } \\
\text { rumah }\end{array}$ & $\begin{array}{l}\text { menguatkan tulang dan } \\
\text { mengobati penyakit kulit }\end{array}$ & 13 \\
\hline 24 & $\begin{array}{l}\text { Kemangi (Ocymum } \\
\text { basilicum) }\end{array}$ & $\begin{array}{l}\text { Sebagai tanaman hias atau nilai } \\
\text { estetika }\end{array}$ & Semak & $\begin{array}{l}\text { Telajakan dan } \\
\text { Pekarangan } \\
\text { rumah }\end{array}$ & $\begin{array}{l}\text { sakit gigi, sakit perut, } \\
\text { demam, dan membantu }\end{array}$ & 55 \\
\hline 25 & $\begin{array}{l}\text { Bugenvil } \\
\text { (Bougainvillea } \\
\text { spectabilis) }\end{array}$ & $\begin{array}{l}\text { Sebagai tanaman hias atau nilai } \\
\text { estetika }\end{array}$ & Perdu & $\begin{array}{l}\text { Telajakan dan } \\
\text { Pekarangan } \\
\text { rumah }\end{array}$ & $\begin{array}{l}\text { batuk, haid tidak lancar, } \\
\text { dan keputihan }\end{array}$ & 69 \\
\hline 26 & $\begin{array}{l}\text { Kembang kertas } \\
\text { (Zinnia elegans) }\end{array}$ & $\begin{array}{l}\text { Sebagai tanaman hias atau nilai } \\
\text { estetika }\end{array}$ & Semak & $\begin{array}{l}\text { Pekarangan } \\
\text { rumah }\end{array}$ & $\begin{array}{l}\text { bisul, kencing nanah, dan } \\
\text { batuk }\end{array}$ & 14 \\
\hline 28 & $\begin{array}{l}\text { Kembang telang } \\
\text { (Clitoria ternatea } \\
\text { L.) }\end{array}$ & $\begin{array}{l}\text { Sebagai tanaman hias atau nilai } \\
\text { estetika }\end{array}$ & Semak & $\begin{array}{l}\text { Pekarangan } \\
\text { rumah }\end{array}$ & $\begin{array}{l}\text { cacingan dan sembelit } \\
\text { (susah buang air besar) }\end{array}$ & 14 \\
\hline 29 & $\begin{array}{l}\text { Kenop } \\
\text { (Gromphrena } \\
\text { globosa L.) }\end{array}$ & $\begin{array}{l}\text { Sebagai tanaman hias atau nilai } \\
\text { estetika }\end{array}$ & Semak & $\begin{array}{l}\text { Pekarangan } \\
\text { rumah }\end{array}$ & $\begin{array}{l}\text { sesak nafas dan } \\
\text { menambah nafsu makan }\end{array}$ & 62 \\
\hline 30 & $\begin{array}{l}\text { Lavender } \\
\text { (Lavandula } \\
\text { angustifolia) }\end{array}$ & $\begin{array}{l}\text { Sebagai tanaman hias atau nilai } \\
\text { estetika }\end{array}$ & Semak & $\begin{array}{l}\text { Pekarangan } \\
\text { rumah }\end{array}$ & $\begin{array}{l}\text { insomnia (tidak bisa tidur) } \\
\text { dan kelelahan }\end{array}$ & 14 \\
\hline 31 & $\begin{array}{l}\text { Legundi (Vitex } \\
\text { tripolia L.) }\end{array}$ & $\begin{array}{l}\text { Sebagai tanaman hias atau nilai } \\
\text { estetika }\end{array}$ & Semak & $\begin{array}{l}\text { Pekarangan } \\
\text { rumah }\end{array}$ & $\begin{array}{l}\text { masuk angin, pusing, dan } \\
\text { menurunkan panas }\end{array}$ & 50 \\
\hline 34 & Mawar (Rosa sp) & $\begin{array}{l}\text { Sebagai tanaman hias atau nilai } \\
\text { estetika }\end{array}$ & Perdu & $\begin{array}{l}\text { Pekarangan } \\
\text { rumah }\end{array}$ & $\begin{array}{l}\text { penyubur rambut dan } \\
\text { mengobati kaki bengkak }\end{array}$ & 7 \\
\hline 35 & $\begin{array}{l}\text { Melati (Jasminum } \\
\text { sambac) }\end{array}$ & $\begin{array}{l}\text { Sebagai tanaman hias atau nilai } \\
\text { estetika }\end{array}$ & Semak & $\begin{array}{l}\text { Pekarangan } \\
\text { rumah }\end{array}$ & $\begin{array}{l}\text { sariawan dan } \\
\text { pembengkakan gusi }\end{array}$ & 4 \\
\hline 36 & $\begin{array}{l}\text { Melati jepang } \\
\text { (Pseuderanthemum } \\
\text { reticulatum) }\end{array}$ & $\begin{array}{l}\text { Sebagai tanaman hias atau nilai } \\
\text { estetika }\end{array}$ & Semak & $\begin{array}{l}\text { Pekarangan } \\
\text { rumah }\end{array}$ & $\begin{array}{l}\text { sesak nafas, sakit kepala, } \\
\text { dan demam }\end{array}$ & 29 \\
\hline 37 & $\begin{array}{l}\text { Nusa indah } \\
\text { (Mussaenda } \\
\text { frondosa) }\end{array}$ & $\begin{array}{l}\text { Tabir untuk mengurangi cahaya } \\
\text { matahari dan sinar lampu } \\
\text { kendaraan }\end{array}$ & Perdu & $\begin{array}{l}\text { Telajakan dan } \\
\text { Pekarangan } \\
\text { rumah }\end{array}$ & $\begin{array}{l}\text { radang tenggorokan, } \\
\text { demam, dan batuk }\end{array}$ & 53 \\
\hline 38 & $\begin{array}{l}\text { Nona makan sirih } \\
\text { (Clerodendrum } \\
\text { thomsonae) }\end{array}$ & $\begin{array}{l}\text { Sebagai tanaman hias atau nilai } \\
\text { estetika }\end{array}$ & Semak & $\begin{array}{l}\text { Pekarangan } \\
\text { rumah }\end{array}$ & $\begin{array}{l}\text { radang selaput gendang } \\
\text { telinga pada anak-anak }\end{array}$ & 4 \\
\hline 39 & $\begin{array}{l}\text { Pacar cina (Aglaia } \\
\text { odorata) }\end{array}$ & $\begin{array}{l}\text { Pembatas untuk privasi atau } \\
\text { pagar }\end{array}$ & Perdu & $\begin{array}{l}\text { Pekarangan } \\
\text { rumah }\end{array}$ & $\begin{array}{l}\text { perut kembung, pusing, } \\
\text { dan batuk }\end{array}$ & 35 \\
\hline 40 & $\begin{array}{l}\text { Pacar air } \\
\text { (Impatiens } \\
\text { balsamina) }\end{array}$ & $\begin{array}{l}\text { Sebagai tanaman hias atau nilai } \\
\text { estetika }\end{array}$ & Semak & $\begin{array}{l}\text { Telajakan dan } \\
\text { Pekarangan } \\
\text { rumah }\end{array}$ & $\begin{array}{l}\text { sakit pinggang dan nyeri } \\
\text { haid }\end{array}$ & 56 \\
\hline 41 & $\begin{array}{l}\text { Pacing tawar } \\
\text { (Costus } \\
\text { speciosus) }\end{array}$ & $\begin{array}{l}\text { Sebagai tanaman hias atau nilai } \\
\text { estetika }\end{array}$ & Semak & $\begin{array}{l}\text { Pekarangan } \\
\text { rumah }\end{array}$ & masuk angin dan diare & 15 \\
\hline
\end{tabular}




\begin{tabular}{|c|c|c|c|c|c|c|}
\hline No & Nama Tanaman & Fungsi dalam lansekap & Habitus & $\begin{array}{c}\text { Tempat } \\
\text { Ditemukan }\end{array}$ & Manfaat Obat & Jumlah \\
\hline & $\begin{array}{l}\text { (Mimosa pudica } \\
\text { L.) }\end{array}$ & estetika & tanah & & batu saluran kencing & \\
\hline 46 & Soka (Ixora sp) & $\begin{array}{l}\text { Pembatas untuk privasi atau } \\
\text { pagar }\end{array}$ & Perdu & $\begin{array}{l}\text { Telajakan dan } \\
\text { Pekarangan } \\
\text { rumah }\end{array}$ & $\begin{array}{l}\text { batuk, terkilir, dan luka } \\
\text { memar }\end{array}$ & 35 \\
\hline 47 & $\begin{array}{l}\text { Tahi Kotok } \\
\text { (Tagetes erecta) }\end{array}$ & $\begin{array}{l}\text { Sebagai tanaman hias atau nilai } \\
\text { estetika }\end{array}$ & Semak & $\begin{array}{l}\text { Telajakan dan } \\
\text { Pekarangan } \\
\text { rumah }\end{array}$ & batuk, sakit gigi dan mual & 45 \\
\hline 48 & $\begin{array}{l}\text { Tapak dara } \\
\text { (Catharanthus } \\
\text { roseus) }\end{array}$ & $\begin{array}{l}\text { Sebagai tanaman hias atau nilai } \\
\text { estetika }\end{array}$ & Semak & $\begin{array}{l}\text { Telajakan dan } \\
\text { Pekarangan } \\
\text { rumah }\end{array}$ & $\begin{array}{l}\text { malaria dan susah buang } \\
\text { air besar }\end{array}$ & 33 \\
\hline 49 & $\begin{array}{l}\text { Tasbih (Canna } \\
\text { indica L.) }\end{array}$ & $\begin{array}{l}\text { Sebagai tanaman hias atau nilai } \\
\text { estetika }\end{array}$ & Semak & $\begin{array}{l}\text { Pekarangan } \\
\text { rumah }\end{array}$ & $\begin{array}{l}\text { demam, wasir, dan } \\
\text { keputihan }\end{array}$ & 10 \\
\hline 50 & $\begin{array}{l}\text { Teratai (Nymphae } \\
\text { sp) }\end{array}$ & $\begin{array}{l}\text { Sebagai tanaman hias atau nilai } \\
\text { estetika }\end{array}$ & $\begin{array}{l}\text { Tanaman } \\
\text { air }\end{array}$ & $\begin{array}{l}\text { Telajakan dan } \\
\text { Pekarangan } \\
\text { rumah }\end{array}$ & $\begin{array}{l}\text { malaria dan susah buang } \\
\text { air besar }\end{array}$ & 34 \\
\hline 51 & $\begin{array}{l}\text { Waru (Hibiscus } \\
\text { tiliaceus L.) }\end{array}$ & $\begin{array}{l}\text { Tabir untuk mengurangi cahaya } \\
\text { matahari dan sinar lampu } \\
\text { kendaraan }\end{array}$ & Pohon & $\begin{array}{l}\text { Telajakan dan } \\
\text { Tegalan }\end{array}$ & $\begin{array}{l}\text { penyubur rambut dan } \\
\text { demam }\end{array}$ & 43 \\
\hline 52 & $\begin{array}{l}\text { Wijaya kusuma } \\
\text { (Epiphyllum } \\
\text { oxypetalum) }\end{array}$ & $\begin{array}{l}\text { Sebagai tanaman hias atau nilai } \\
\text { estetika }\end{array}$ & Perdu & $\begin{array}{l}\text { Pekarangan } \\
\text { rumah }\end{array}$ & $\begin{array}{l}\text { nyeri lambung dan sesak } \\
\text { nafas }\end{array}$ & 1 \\
\hline
\end{tabular}

Tabel 2. Fungsi Tanaman Obat-obatan sebagai Elemen Lunak pada Lansekap

\begin{tabular}{cll}
\hline No & \multicolumn{1}{c}{ Fungsi dalam Lansekap } & \multicolumn{1}{c}{ Jenis Tanaman } \\
\hline 1 & $\begin{array}{l}\text { Sebagai pemberi batas untuk privasi } \\
\text { atau pagar } \\
\text { Sebagai tabir untuk mengurangi } \\
\text { cahaya matahari dan lampu kendaraan } \\
\text { yang menyilaukan }\end{array}$ & $\begin{array}{l}\text { Beluntas, jarak, kaca piring, kapas, kembang sepatu, melati jepang, } \\
\text { pacar cina, melati, soka, waru } \\
\text { Cempaka, nusa indah, waru }\end{array}$ \\
3 & Penyerap polutan & Bungur \\
4 & Nilai Estetika & Alamanda, beluntas, binahong, biduri, boroco, bunga pagoda, \\
& & $\begin{array}{l}\text { bunga lilin, bakung air mancur, jengger ayam, kaktus pakis giwang } \\
\text { kapas, kamboja, kembang kertas, kembang ratna, kembang telang, } \\
\text { kembang cokelat, kecombrang, kenop, ketepeng cina, kemanggi, } \\
\text { kumis kucing, lavender, legundi, lengkuas merah, lotus, teratai, } \\
\text { mawar, melati, nona makan sirih, pacar air, pacing tawar, pecut } \\
\text { kuda, portulaka, poslen, soka, tasbih, wijaya kusuma }\end{array}$ \\
& & \\
&
\end{tabular}

\subsection{Pembahasan}

\subsubsection{Tanaman Obat-obatan yang Paling Banyak Dipergunakan sebagai Elemen Lunak Lansekap di Kecamatan Kediri}

Berdasarkan hasil penelitian menunjukkan bahwa terdapat 52 jenis tanaman obatobatan di Kecamtan Kediri dengan jumlah 1569 tanaman (Tabel 1). Terdapat 27 jenis tanaman semak, 17 jenis tanaman perdu, dua jenis tanaman air, empat jenis tanaman pohon dan dua jenis tanaman penutup tanah (Tabel 1) yang ditemukan di tiga area yaitu telajakan, pekarangan rumah, dan tegalan. Tanaman yang dipergunakan dan ditanam dikelompokkan berdasarkan habitus yaitu pohon, perdu, semak, penutup tanah, dan 
tanaman air. Tanaman kamboja (Plumeria sp.) paling banyak dipergunakan dan ditanam dengan jumlah 192 tanaman (Tabel 1), karena mudah dirawat dan dipergunakan untuk upakara, sesuai pendapat Sardiana (2012), bunga kamboja dipergunakan untuk (canang) dan persembahyangan. Tanaman paling sedikit ditanam dan dipergunakan adalah wijaya kusuma (Epiphyllum oxypetalum) didapatkan dua tanaman (Tabel 1), karena lama berbunga dan bunganya hanya dapat bertahan satu hari. Menurut Agus (2008), tanaman kamboja dan wijaya kusuma dapat dimanfaatkan sebagai obat sakit gigi, nyeri lambung, dan sesak nafas.

\subsubsection{Tanaman Obat-obatan yang Belum Dikelompokkan ke dalam Elemen Lunak Lansekap}

Berdasarkan tanaman obat-obatan yang ditemukan di rumah warga yang diamati terdapat delapan jenis tanaman yang belum dikelompokkan ke dalam elemen lunak lansekap berdasarkan belum dibudidayakan adalah boroco (Celosia argentia), ketepeng cina (Cassia alata L), pecut kuda (Stachytarpheta jamaicensis), dan putri malu (Mimosa pudica L), karena tumbuhnya masih liar sehingga belum dibudidayakan. Sesuai pendapat Dalimartha (2003), tanaman boroco (Gambar 1), ketepeng cina (Gambar 2), pecut kuda (Gambar 3), dan putri malu (Gambar 4) tumbuhnya liar dan tanaman ini tidak memerlukan perawatan yang khusus, seperti pemupukan atau penyiraman dan dapat tumbuh diatas permukaan tanah yang lembab maupun tanah yang gersang. Selain itu tanaman boroco, ketepeng cina, pecut kuda, dan putri malu dapat dimanfaatkan sebagai obat menurunkan panas, tekanan darah tinggi, mimisan, dan keputihan.

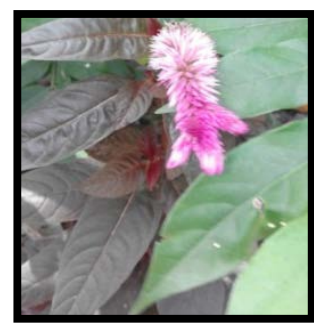

Gambar 1. Boroco

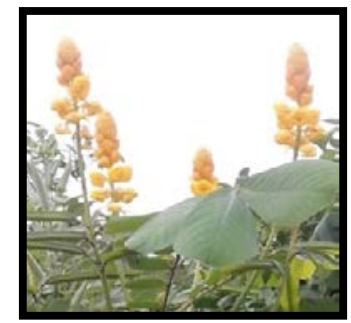

Gambar 2. Ketepeng Cina

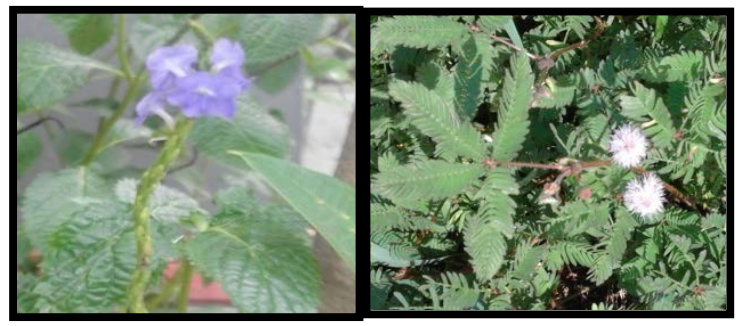

Gambar 3. Pecut Kuda

Gambar 4. Putri Malu

\subsubsection{Fungsi Tanaman Obat-Obatan sebagai Elemen Lunak Lansekap}

Berdasarkan hasil wawancara dengan masyarakat di Kecamatan Kediri dapat diketahui bahwa tanaman obat-obatan sebagai elemen lunak lansekap difungsikan berbeda-beda di antaranya, sebagai pagar, peneduh, penyerap polutan dan keindahan (Tabel 2). Tanaman yang dipergunakan sebagai tabir untuk mengurangi cahaya matahari dan lampu kendaraan yang menyilaukan adalah cempaka, nusa indah dan waru (Tabel 2). Tanaman yang dipergunakan sebagai penyerap polutan yaitu bungur (Tabel 2), sesuai dengan pendapat Arifin (2006) bahwa, tanaman bungur dapat mengurangi dan menurunkan tingkat pencemaran udara dengan cara menyerap polutan, selain itu tanaman bungur mempunyai daya serap polutan paling tinggi dan kerusakan pada daunnya rendah. Tanaman yang dipergunakan sebagai nilai estetika yaitu alamanda, binahong, biduri, boroco, bunga pagoda, bunga lilin, bakung air mancur, jengger ayam, kaktus pakis giwang, 
kamboja, kembang kertas, kembang telang, kembang cokelat, kecombrang, kenop, ketepeng cina, kumis kucing, lavender, legundi, lengkuas merah, lotus, teratai, mawar, melati, nona makan sirih, pacar air, pacing tawar, pecut kuda, portulaka, poslen, soka, tasbih, dan wijaya kusuma (Tabel 2).

Tanaman obat-obatan yang digunakan sebagai elemen lunak lansekap di Kecamatan Kediri memiliki fungsi yang ganda yaitu sebagai tanaman obat dan sebagai tanaman hias yang memiliki nilai estetika. Masyarakat Kecamatan Kediri menganggap menggunakan tanaman yang memiliki fungsi ganda sebagai elemen lunak lebih menguntungkan, selain itu untuk menambah pengetahuan masyarakat tentang tanaman obat-obatan. Tanaman obat-obatan sebagai elemen lunak lansekap dapat dinikmati keindahan tanamannya dan ketika diperlukan untuk kesehatan akan lebih mudah untuk mendapatkannya. Tanaman merupakan salah satu elemen pembentuk pagar, sehingga dapat menjadi alternatif sebagai pagar sebuah lansekap, selain itu tanaman memiliki fungsi yang beragam seperti sebagai tabir untuk mengurangi cahaya matahari dan lampu kendaraan yang menyilaukan, pembatas untuk privasi, penyerap polutan dan estetika (Carpenter et al. 2000 dalam Gray, 2011). Tanaman merupakan salah satu elemen lansekap yang dapat berperan sebagai pemberi kenyamanan pada pemiliknya dan fungsi tanaman dalam desain pertamanan adalah sebagai tabir untuk mengurangi cahaya matahari dan sinar lampu kendaraan dengan menempatkan tanaman pada ketinggian dan kepadatan yang tepat untuk menutupi pemandangan yang kurang baik.

\subsubsection{Tata Letak dan Fungsi Tanaman}

\subsubsection{TelajakanS}

Berdasarkan hasil survei tanaman obat-obatan yang diletakkan di telajakan sampel yang diamati terdapat empat jenis tanaman berhabitus pohon, 12 jenis tanaman berhabitus perdu, 20 jenis tanaman habitus semak, dua jenis tanaman berhabitus penutup tanah, dan dua jenis tanaman berhabitus tanaman air (Tabel 1). Jenis tanaman yang cocok ditanam pada telajakan yaitu cempaka (Michelia champaca), waru (Hibiscus tiliaceus L.), dan kamboja (Plumeria sp.). Sesuai pendapat Dwijendra (2010), tanaman cempaka, waru, dan kamboja cocok ditanam telajakan karena memiliki kriteria daun rimbun dengan kerapatan daun yang bisa menutupi sinar matahari, perawatannya mudah, daunnya tidak mudah rontok, ranting atau cabang tidak berukuran besar, dan tanamannya tidak terlalu tinggi. Pada umumnya tanaman yang diletakkan pada telajakan berfungsi sebagai peneduh, tanaman hias, tabir untuk mengurangi cahaya matahari dan sinar lampu kendaraan, serta pagar atau pembatas untuk privasi.

\subsubsection{Pekarangan rumah}

Tanaman obat-obatan yang diletakkan pada pekarangan rumah responden didapatkan dua jenis tanaman berhabitus pohon, 16 jenis tanaman berhabitus perdu, 16 jenis tanaman berhabitus semak, dan dua jenis tanaman berhabitus tanaman air (Tabel 1). Pada umumnya tanaman yang diletakkan di pekarangan rumah berfungsi sebagai estetika dan ditanam jenis tanaman hias bunga. Jenis tanaman bunga yang cocok ditanam di pekarangan rumah yaitu tanaman kamboja, melati, kembang sepatu, kaca piring, mawar, 
soka, dan kaktus pakis giwang, didukung oleh pendapat Setiawan (2001) tanaman ini diyakini membawa pengaruh kesucian dan keindahan, serta dapat mempercantik taman pekarangan rumah agar terlihat asri dan nyaman.

\subsubsection{Tegalan}

Hasil survei tanaman obat-obatan yang diletakkan di tegalan dari sampel yang diamati didapatkan satu jenis tanaman berhabitus pohon, lima jenis tanaman berhabitus perdu dan sembilan jenis tanaman berhabitus semak (Tabel 1). Jenis tanaman yang ditanam di tegalan yaitu waru dan bungur, sesuai pendapat Dwijendra (2010), tanamantanaman tersebut cocok ditanam di tegalan karena memiliki daun rimbun, berukuran besar dan tinggi yang difungsikan sebagai peneduh. Contoh posisi letak telajakan, pekarangan rumah, dan tegalan dapat dilihat pada Gambar 5 di bawah ini.

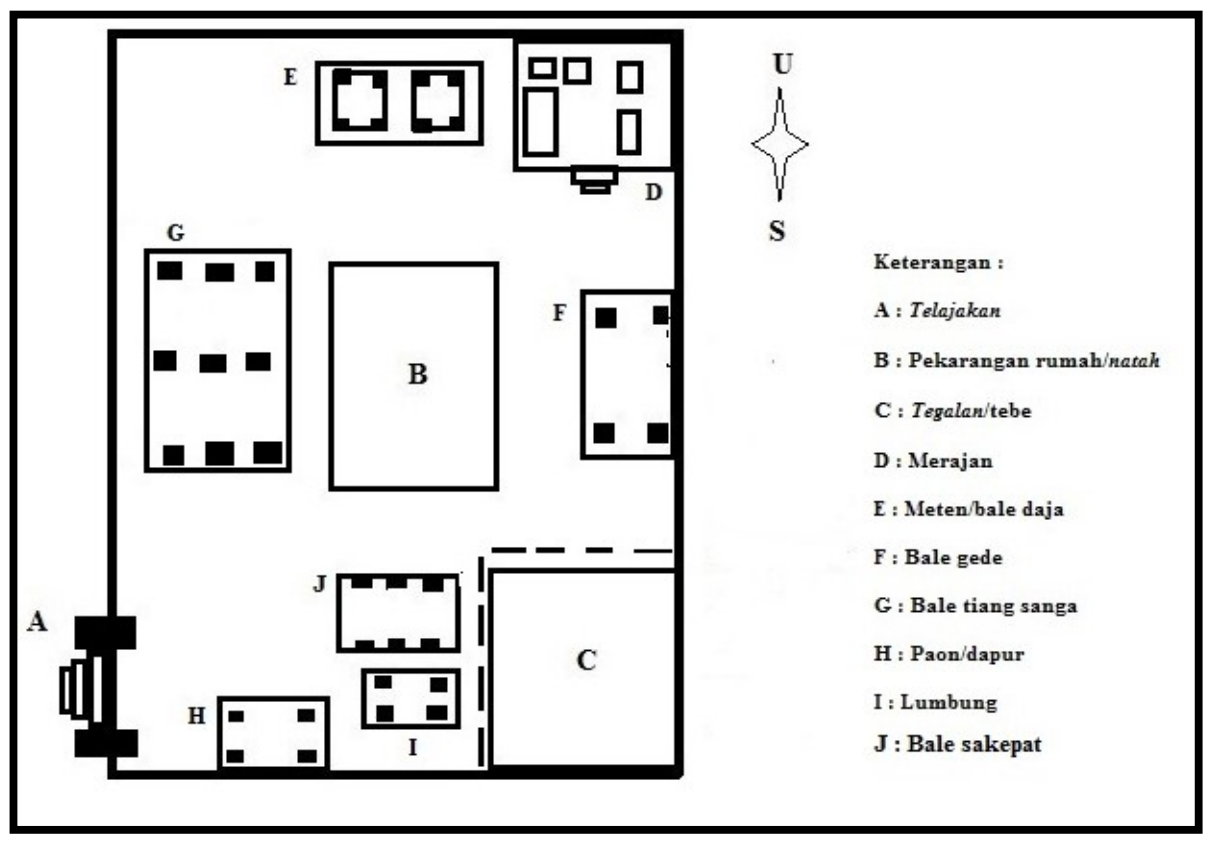

Gambar 5 Contoh Gambar Denah Rumah Sampel yang Diambil (Rumah Bapak Mustrawan)

\section{Simpulan dan saran}

\subsection{Simpulan}

Berdasarkan uraian diatas dapat disimpulkan bahwa:

1. Lokasi atau wilayah studi yang diobservasi telah ditemukan dan teridentifikasi 52 jenis tanaman obat-obatan berbunga yang dikelompokkan menjadi lima habitus yaitu semak, perdu, tanaman air, pohon, dan penutup tanah.

2. Tanaman obat-obatan berbunga yang belum dikelompokkan ke dalam elemen lunak lansekap adalah boroco (Celosia argentia), ketepeng cina (Cassia alata), pecut kuda (Stachytarpheta jamaicensis), dan putri malu (Mimosa pudica), karena tumbuhnya masih liar sehingga belum dibudidayakan

3. Terdapat empat fungsi tanaman obat-obatan berbunga yang telah terinventarisasi dan teridentifikasi sebagai elemen desain lansekap yaitu sebagai pagar, peneduh, penyerap polutan, dan keindahan. 


\subsection{Saran}

1. Tanaman yang belum dikelompokkan ke dalam elemen lunak lansekap dapat dijadikan tanaman lansekap.

2. Sebaiknya pemerintah Kecamatan Kediri memberikan penyuluhan mengenai tanaman obat-obatan kepada masyarakat untuk menambah pengetahuan masyarakat tentang tanaman obat-obatan.

\section{Daftar Pustaka}

Agus. 2008. Tanaman Obat Indonesia. Salemba Medika. Jakarta. 200 halaman

Arifin. 2006. Potensi Tanaman Polutan terhadap Pencemaran Udara di Kota Surabaya. Skripsi Fakultas Pertanian Universitas Pembangunan Nasional Veteran Jawa Timur. Dalimartha. 2003. Atlas Tumbuhan Obat Indonesia. Penerbit Pustaka Pembangunan Swadaya Nusantara. Jakarta. 197 halaman

Dwijendra, N. K. A. 2010. Arsitektur Rumah Tradisional Bali. Udayana University Press. Denpasar. 247 halaman

Harrington \& Gill. 2008.Occupational Health. Blackwell Scientific Publlication,Oxford. Journal of Oxford University. New York. 6 (2):13-16.

Gray. 2011. Plant in the Landscape Design. Journal of Engineering Florida University.7 (2):10-14.

Sardiana, I. K. N. M. Wiasti, dan I.N. Wardi. 2012. Etnobotani Bali. Udayana University Press. 203 halaman.

Setiawan. 2001. Bidang Istilah Arsitektur Tradisional Bali. Upada Sastra. Denpasar. 360 halaman.

Wijayakusuma. 2007. Indonesia Gudangnya Habitat Tanaman Obat Dunia. URL : http://gudangnya-habitat-tanaman-obat-dunia. Diakses tanggal 16 September 2015. 